ORIGINAL RESEARCH ARTICLE

\title{
Mediterranean shrublands as carbon sinks for Climate Change mitigation: new root to shoot ratios
}

(Received 29 October 2016; accepted XX)

\begin{abstract}
Shrublands play an important role in the reduction of atmospheric $\mathrm{CO}_{2}$ and contribute to the mitigation of the effects of Climate Change, due to their ability to act as carbon sinks and the large expanses of land involved. Two of the most representative shrub species in the Iberian Peninsula, Cistus ladanifer L. and Erica arborea L., were studied in terms of biomass distribution and carbon and nitrogen contents in the different fractions. With a view to fast and cost-effective estimation of radical biomass, a new procedure for facile root-to-shoot calculation based on vibrational data was proposed, resulting in an excellent agreement with the values obtained from conventional direct belowground and aerial biomass measurements: 0.23 for $C$. ladanifer and 0.54 for $E$. arborea. Carbon sequestration, estimated at 45 and 73 $\mathrm{t} \mathrm{CO}_{2} \mathrm{eq} \cdot \mathrm{ha}^{-1}$ for $C$. ladanider and $E$. arborea, respectively, was subsequently determined. Since these values are substantially higher than those of other shrubs, these two key species can be deemed as particularly promising for ecological restoration and carbon offsetting.
\end{abstract}

Keywords: Cistus ladanifer L.; Climate Change mitigation; $\mathrm{CO}_{2}$ sinks; Erica arborea L.; shrubland; root to shoot ratio. 


\section{Introduction}

Under the right conditions, woodlands and shrublands play an important role in the reduction of atmospheric $\mathrm{CO}_{2}$ due to their ability to act as carbon sinks (Watson and Noble 2002). However, the efficiency of the activities aimed at this reduction should maintain a positive balance between the absorbed and released carbon, and the ability to estimate these quantities and to gain insight into the carbon dynamics should then be regarded as essential requisites (OrellanaRivadeneyra et al. 2012). It is in this context, the European Union is funding lines of research (such as project " $\mathrm{CO}_{2}$ Operation", sponsored by LIFE+ program) focused on demonstrating the viability of forestry and agroforestry carbon sequestration projects, extending the (carbon credits) green economy as an alternative for future development and significantly contributing to the fight against Climate Change.

At present, there are different approaches to estimate biomass and carbon stocks in forests, based on information from forest inventories and referred to factors or biomass equations. These formulas transform diameter, weight or volume data into carbon or biomass estimates (Somogyi et al. 2007).

According to Montero, Pasalodos-Tato, Montoto, et al. (2013), in Spain there is abundant information on some tree species (Ibàñez, Vayreda, and Gracia 2002, Montero, Ruiz-Peinado, and Muñoz 2005, Ruiz-Peinado, del Rio, and Montero 2011, Ruiz-Peinado, Montero, and Del Rio 2012), but that on bushes and thickets formations is much more limited (Alías et al. 2015, García Rosa 2013, Blanco Oyonarte and Navarro Cerrillo 2003, Castro et al. 1996, Navarro 2004, Cerrillo and Oyonarte 2006, Mendoza-Ponce and Galicia 2010, Paton et al. 1997). Ruiz-Peinado, Montero, and Del Rio (2012) emphasized the importance of the role that shrubs play in water-limited agro-silvo-pastoral systems by providing shelter and forage for livestock, controlling erosion, maintaining biodiversity, diversifying the landscape, and above all, facilitating tree regeneration. Early successional shrublands have become dominant because of the abandonment of agricultural fields and the increase in wildfires frequency in recent decades (Masalles and Vigo 1987). Furthermore, the carbon sink capacity of shrubs could also help to mitigate the effects of Climate Change, since they account for a high proportion of the total plant biomass (RuizPeinado, Montero, and Del Rio 2012).
Some studies have evinced the existence of some variability in the carbon content not only between species but also between different biomass fractions (Montero, Pasalodos-Tato, Montoto, et al. 2013, García Rosa 2013, Gayoso A and Guerra C 2005, Lin, Liu, and Lin 2002, Alías Gallego et al. 2009), in spite of the fact that the overall average approaches $50 \%$-the mean value proposed by Kollmann (1959) and accepted by the IPCC-. Given the ecological role of these formations and their size in the Iberian Peninsula mountains, it is essential to quantify the biomass, carbon and nitrogen content differential ratios both at intra- and interspecies levels.

The study presented herein focuses on two of the most representative shrub species of the Iberian Peninsula, namely Cistus ladanifer L. and Erica arborea L. (Figure 1), which occupy surfaces of over 2,100,000 ha and 2,400,000 ha, respectively (MAPAMA 2016). They have a wide distribution, according to the Spanish Forest Map (MAPAMA 2006) and the Anthos Spanish Plants Information System (Spanish Biodiversity Foundation and Spanish Royal Botanic Garden 2011), and also appear accompanying tree species, in such a way that they have their own codification in the Spanish National Forest Inventory (MAPAMA 2016). Phytosociologically, these species are very important in pure Mediterranean shrublands, in siliceous soils (Serrada, Montero, and Reque Kilchenmann 2008), and Cistus ladanifer has a relevant role as an animal feed source (Serrada, Montero, and Reque Kilchenmann 2008). These species are represented in various habitats of the Council Directive 92/43/EEC.

Fractions of these two species, grown under the same conditions, have been assessed, placing particular emphasis on an accurate determination of their radical biomass, provided that the literature tends to underestimate rootshoot ratios $(R)$ according to Mokany, Raison, and Prokushkin (2006). The aim of this work has been to obtain these ratios, since they are an expansion factor used for inferring belowground biomass from aboveground biomass measurements (IPCC 2006) and, provided that it is based on biomass and carbon, it can provide ecological values for the calculation of stock, production and ecosystem productivity that are closer to reality.

[FIG. 1] 


\section{Material and methods \\ Location}

The study was carried out on a plot located in the municipality of Ayoó de Vidriales $\left(42^{\circ} 07^{\prime} 10^{\prime \prime} \mathrm{N}\right.$, $\left.6^{\circ} 06^{\prime} 59^{\prime \prime} \mathrm{W}\right)$, in the province of Zamora, Castilla $y$ Leon, Spain (Figure 2). The chosen area ( $>1.2 \mathrm{ha}$ ) is a mixed shrubland in which the dominant shrub species are Erica arborea L. (Ea) and Cistus ladanifer L. $(\mathrm{Cl})$.

With a continental climate -typical of the northern plateau of the Iberian Peninsula-, temperatures are extreme, with monthly average temperature values ranging from $-2{ }^{\circ} \mathrm{C}$ to $25^{\circ} \mathrm{C}$. Rainfall is scarce (about $440 \mathrm{~mm}$ per year), with a pronounced drought period from late May to midSeptember. The soil belongs to Inceptisols (i.e., soils of relatively new origin, characterized by having only the weakest appearance of horizons, or layers, produced by soil-forming factors), suborder Ochrept (i.e., it is a young soil with thin, light colored horizons), with a xeric moisture regime (Xerochept).

\section{[FIG. 2]}

\section{Data sampling and fresh weight determination}

Calculations for the estimation of biomass and carbon stocks may be obtained either by direct or by indirect methods (Sanquetta et al. 2004). Direct methods involve the destruction of heavy biomass, whereas in indirect methods regression models are used to estimate stored biomass and carbon from measurements of other variables -such as DBH (diameter at breast height), tree height $(\mathrm{H})$ or age-, making the process easier (Sanquetta, Corte, and da Silva 2011).

In the first part of this study, biomass was determined by a destructive method, which comprised the selection, felling and extraction of biomass for each of the species (conducted in December 2013). Selected samples corresponded to healthy individuals and featured similar characteristics to the rest of the population. The aerial part was separated from the roots using a saw and then, following an analogous procedure to that described by Ruiz-Peinado, Montero, and Del Rio (2012), root systems were excavated by using a tractor with a shovel and then spades were used to complete the job. For each plant, soil was excavated down in a circular area of twice the mean crown diameter. In addition to the main body of the roots, those remaining in the hole were also collected.
25 samples of each species were transported to the laboratory (ETSIIAA facilities, Universidad de Valladolid, Spain), where they were separated into different fractions and weighed (fresh weight). In the case of Cistus ladanifer, they were classified into leaves, fruits, thin branches $(3-7 \mathrm{~mm}$ in diameter), thick branches (7-17 $\mathrm{mm}$ in diameter) and roots. On the other hand, for Erica arborea given its morphology and the impracticality of leaves separation- they were divided into four fractions: leaves with flowers and fruits, fine material $(<1 \mathrm{~cm})$, thick material $(<5 \mathrm{~cm})$ and roots, in agreement with de Mello et al. (2012).

\section{Dry matter content}

The dry matter (biomass) content was empirically determined by extracting subsamples from each fraction. The fractions of the aerial parts were dried in oven at $102 \pm 2^{\circ} \mathrm{C}$ until constant weight was attained (at which the water content was assumed to be zero). The roots, because of their size, were weighted once their moisture was balanced with the environment (i.e., air-dried) and the results were crosschecked by comparison with those obtained for some fractions dried in the stove. The dry matter content for each component was calculated, in agreement with de Mello et al. (2012), using the following expression:

$$
\text { Dry matter }(\%)=\frac{\mathrm{W}_{\text {dry }}}{\mathrm{W}_{\text {fresh }}} \cdot 100 \quad \text { [Eq. 1] }
$$

where $W_{d r y}$ is the dry weight $(\mathrm{g})$ and $W_{\text {fresh }}$ is the fresh weight $(\mathrm{g})$.

Subsequently, each fraction was ground in a ball mill and homogenized to obtain $1 \mathrm{~mm}$ sieve powder (the fruits of the gum rockrose and some thick stem elements required a hydraulic press, given the resistance of the structure to grinding) for $\mathrm{CHN}$ analysis (discussed below).

\section{Root-to-shoot ratio as indicator of the relationship between the belowground and aerial biomass}

Root-to-shoot ratios can be applied to individual plants or to stands of vegetation at a local, landscape, regional or biome scale (Mokany, Raison, and Prokushkin 2006), and they are often considered as constant or species/area specific values in most studies (Wang, Duan, and Zhang 2011). The root-to-shoot ratio is defined by the IPCC (2006) as the ratio of belowground (root) to aboveground (shoot) biomass -including leaves, thin branches and thick branches-, as follows:

$$
\mathrm{R}=\frac{\mathrm{W}_{\text {root }}}{\mathrm{W}_{\text {shoot }}}
$$


where $R$ is the root-to-shoot ratio (dimensionless), $W_{\text {root }}$ is the root dry weight $(\mathrm{g})$ and $W_{\text {shoot }}$ is the aboveground dry weight $(\mathrm{g})$.

The use of the root-to-shoot ratio as an indicator of the relationship between the belowground (root biomass) and aerial biomass (the sum of leaves, thin branches and thick branches biomasses) is particularly important, since it can serve as an estimator of belowground carbon based on a simple biometric survey of aboveground biomass with lower costs (Schenk and Jackson 2002). Consequently, realistic root-to-shoot ratios play a key role in the improvement of the accuracy of estimates of root biomass and, in turn, in the estimation of the effects of management and landuse changes in national inventories of greenhouse gas emissions (Mokany, Raison, and Prokushkin 2006).

The equations for the obtaining of the $R$ value may vary from project to project. Individual standard values are frequently used, such as those proposed by Kauppi, Mielikainen, and Kuusela (1992), Kauppi, Tomppo, and Ferm (1995), Löwe, Seufert, and Raes (2000), UN-ECE/FAO (2000), Federici et al. (2015) and IPCC (2006). Nevertheless, it is known that these factors also vary depending on the species, the growth stage and the location: the $R$ biomass ratio of adult plants in Mediterranean ecosystems tends to be higher than in more temperate ecosystems, possibly as an adaptation to the summer dry season (Hilbert 1990, Lloret, Casanovas, and Penuelas 1999). Consequently, calculations were performed under specific and identical conditions for the samples of the two species under study, in agreement with Sanquetta, Corte, and da Silva (2011).

\section{FTIR spectroscopy as new tool to determine root- to-shoot ratios}

Fourier transform infrared (FTIR) spectroscopy is a useful analytical technique for the nondestructive characterization of biological specimens. It is regarded as a rapid and accurate method for the fast and simultaneous qualitative and quantitative characterization of natural products and their constituents (Huck 2015). Molecular bonds with an electric dipole moment that can change by atomic displacement owing to natural vibrations are IR active. These vibrational modes are quantitatively measurable by FTIR spectroscopy (Griffiths and Haseth 2007, Baker et al. 2014).

The FTIR spectra of leaves, thin branches, thick branches and roots of $C$. ladanifer and E. arborea were collected in direct transmittance mode using a
Thermo Nicolet iS50 spectrometer (Thermo Fisher Scientific, Waltham, MA, USA) and the potassium bromide $(\mathrm{KBr})$ pellet method. $13 \mathrm{~mm}$-diameter pellets were obtained by mixing $1.0 \mathrm{wt} \%$ sample into $200 \mathrm{mg}$ of fine $\mathrm{KBr}$ powder and then finely pulverizing and putting into a pellet-forming die. A force of approximately 8 tons was applied under a vacuum of several $\mathrm{mm} \mathrm{Hg}$ for several minutes to form transparent pellets. Spectra were recorded in the mid-infrared range $\left(4000-400 \mathrm{~cm}^{-1}\right)$ at a spectral resolution of $4 \mathrm{~cm}^{-1}$, taking 32 scans per sample. Background scanning and correction was carried out at $60 \mathrm{~min}$ intervals, using a pure $\mathrm{KBr}$ pellet for the background spectra to correct for infrared light scattering losses in the pellet and for moisture adsorbed on the $\mathrm{KBr}$ (Evans 1991, Owen and Thomas 1989, Chen et al. 2010).

The vibrational data were analyzed with OMNIC v.9.3.32 (Thermo Fisher Scientific) software, focusing on the fingerprint region (1900$800 \mathrm{~cm}^{-1}$ ), in which most of the variations of infrared absorption occur. Within the fingerprint region, four wavenumbers were selected for the calculation of the shoot-to-root ratios: $1369 \mathrm{~cm}^{-1}$, attributable to the $\mathrm{C}-\mathrm{H}$ and $\mathrm{C}-\mathrm{O}$ groups of the hexose ring in cellulose; $1458 \mathrm{~cm}^{-1}$, consistent with the saccharide backbone; $1514 \mathrm{~cm}^{-1}$, attributed to the $\mathrm{C}=\mathrm{C}$ stretching vibration in the aromatic skeletal vibration in lignin; and $1730 \mathrm{~cm}^{-1}$, assigned to ester linkage of the carboxylic group in hemicelluloses.

Root-to-shoot ratios for both species, $C$. ladanifer and E. arborea, based on vibrational data were calculated using the corrected peak areas at the four wavenumbers indicated above and equation 3 :

$$
\mathrm{R}_{\lambda}=\frac{\mathrm{A}_{\text {root }}}{\mathrm{A}_{\text {shoot }}}=\frac{\text { roots }}{\text { (leafs }+ \text { thin branches+thick branches) }}
$$

$$
\text { [Eq. 3] }
$$

where $R_{\lambda}$ is the root-to-shoot ratio (dimensionless) for each wavenumber; $A_{\text {root }}$ is the area of the peak in the roots sample; and $A_{\text {shoot }}$ is the aboveground peak area, i.e., the summation of the peak areas in the leaves, thin branches and thick branches samples. As noted above, these ratios are often regarded as constant or species/area specific values (Wang, Duan, and Zhang 2011).

It should be clarified that the peak height depends on the number of molecules present (concentration) and on the strength of the absorption (absorptivity). Conversely, the area of the peak is regarded as a better indicator of concentration, because the final peak profile is the sum of all the individual elements. Whereas in some cases the peak height can be changed by a broadening problem, the area will remain 
unchanged, as the total number of molecules is constant.

The corrected areas (defined as the areas under the spectrum bordered with a baseline) in the spectral regions of interest were determined with OMNIC software, using the automatic baseline correction procedure prior to area calculation. Figure 3 shows how the areas at each selected wavenumber were calculated, taking the fingerprint region of the vibrational spectrum of $E$. arborea leaves as an example.

\section{[FIG. 3]}

\section{Carbon and nitrogen determination in the laboratory}

The determination of the carbon and nitrogen concentrations was conducted using a LECO CHN2000 analyzer (LECO Corp., Saint Joseph, MI, USA). Ethylenediaminetetraacetic acid, 99\%; CAS No. 60-00-4), purchased from Alfa Aesar (Thermo Fisher (Kandel) GmbH, Karlsruhe, Germany), was used for the analyzer calibration in four replicates from 0.09 to $0.12 \mathrm{~g}$, while the weight of the samples of the two shrubs under study was always $0.10 \mathrm{~g}$ (measured in a precision scale). Samples were individually wrapped in tin foil and shaped into spheres and, subsequently, they were placed in an autosampler that loaded them into the apparatus. The automated system performed the combustion of samples at a temperature of $900{ }^{\circ} \mathrm{C}$ and the remaining products of combustion $\left(\mathrm{CO}_{2}, \mathrm{H}_{2} \mathrm{O}, \mathrm{O}_{2}\right.$, $\mathrm{N}_{2}$ and $\mathrm{NO}_{\mathrm{x}}$ ) were collected and mixed thoroughly. $\mathrm{CO}_{2}$ and $\mathrm{H}_{2} \mathrm{O}$ levels were monitored by two independent selective non-dispersive infrared detectors, and $\mathrm{N}_{2}$ was determined by a thermal conductivity detector. The apparatus directly provided the weight-compensated results as a percentage of carbon and nitrogen content in each fraction.

There are many studies about the allocation of nitrogen in the plants, provided that it changes as a function of the species and time of the year. However, there is a strong linear relationship between plant nitrogen concentration and the fraction of mass allocated to leaves (Hilbert 1990, Agren and Ingestad 1987):

$$
P \cdot S=\frac{d N}{d t}=a N
$$

where $P$ is the net photosynthesis, $S$ is the fraction of mass allocated to leaves, $N$ is the nitrogen concentration, and $a$ is a constant.

\section{Indirect calculation of carbon stock}

Aboveground biomass was estimated from the equations proposed by Montero, Pasalodos-Tato, López-Senespleda, et al. (2013) for Mediterranean shrublands. These equations, deemed as accurate for large expanses of territory, are based on data from the canopy cover and average height of different species of Mediterranean shrublands and provide tons of dry matter per hectare, differing according to taxonomic affinities. The species analyzed herein belong to the formations classified as 'gum rockroses and Cistaceae shrublands' [tr.] and 'briar roots and Ericaceae shrublands' [tr.], and their respective equations are as follows:

$$
\begin{gathered}
\ln \left(\mathrm{W}_{\mathrm{a} \mathrm{Cl}}\right)=-2.596+0.957 \cdot \ln \left(\mathrm{H}_{\mathrm{av} \mathrm{Cl}}\right)+ \\
0.747 \cdot \ln \left(\mathrm{FCC}_{\mathrm{av} \mathrm{Cl}}\right) \\
\operatorname{lEq} .5] \\
\ln \left(\mathrm{W}_{\mathrm{a} \mathrm{Ea}}\right)=-2.921+0.984 \cdot \ln \left(\mathrm{H}_{\mathrm{av} \mathrm{Ea}}\right)+ \\
0.863 \cdot \ln \left(\mathrm{FCC}_{\mathrm{av} \mathrm{Ea}}\right)
\end{gathered}
$$

where $W_{a}$ is the amount of aboveground biomass, in tons of dry matter per hectare (tons DW·ha ${ }^{-1}$ ); $H_{a v}$ stands for the average height of the shrub expressed in decimeters $(\mathrm{dm})$; and $F C C_{a v}$ represents the canopy cover of the shrub expressed in $\%$.

The root biomasses of each of the shrub species were estimated by applying the value of the root-toshoot ratios determined in previous sections to the aboveground biomass calculated for each hectare of shrubland. The average height was measured by a sample inventory with a range pole, and the canopy cover was determined through GIS (Geographic Information Systems) tools, using LARS (Low Altitude Remote Sensing) data collected with a remotely piloted aircraft (RPA).

The total amount of carbon stored was predicted using the experimentally determined carbon content of each fraction. Thus, the tons of carbon per hectare of shrubland were estimated using equation 7:

$$
\begin{gathered}
\mathrm{C}_{\mathrm{t}}=\left[\mathrm{W}_{\mathrm{a} \mathrm{Cl}} \cdot\left(\mathrm{CC}_{\text {shoot } \mathrm{Cl}}+\mathrm{R}_{\mathrm{Cl}} \cdot \mathrm{CC}_{\text {root Cl }}\right)+\right. \\
\left.\mathrm{W}_{\mathrm{a} \mathrm{Ea}} \cdot\left(\mathrm{CC}_{\text {shoot Ea }}+\mathrm{R}_{\mathrm{Ea}} \cdot \mathrm{CC}_{\text {root Ea }}\right)\right] \cdot \mathrm{S} \\
{[\text { Eq. 7] }}
\end{gathered}
$$

where $C_{t}$ is the total assimilated carbon (tons), $W_{a}$ is the aboveground biomass (tons $\cdot \mathrm{ha}^{-1}$ ), $R$ is the rootto-shoot ratio, $C C$ is the amount of carbon absorbed by each fraction of biomass (\%), and $S$ is the surface (ha).

\section{Results and discussion \\ Biomass distribution and root-to-shoot ratios}

Figure 4 shows the biomass distribution in each plant: C. ladanifer has $19 \%$ of leaves, $1 \%$ of capsules, $29 \%$ of thin branches, $33 \%$ of thick branches and $18 \%$ of roots; versus E. arborea with 
$4 \%$ of leaves, $20 \%$ of thin branches, $41 \%$ of thick branches and $35 \%$ of roots (represented in the figure in the clockwise direction). Thus, in C. ladanifer the aboveground biomass accounted for $3.98 \mathrm{~g}$, roughly $81.8 \%$ of the total dry mass, whereas belowground (roots) accounted for $0.89 \mathrm{~g}, 18.2 \%$. On the other hand, in E. arborea root biomass $(8.06 \mathrm{~g})$ represented $35.3 \%$ of the total dry mass, while the remaining $64.6 \% \quad(14.72 \mathrm{~g})$ corresponded to aboveground biomass.

Consequently, the root-to-shoot ratios, calculated as the quotients of 18.2 by 81.8 and 35.8 by 64.6 , were $R=0.22$ for $C$. ladanifer and $R=0.55$ for $E$. arborea.

The distribution of biomass -and therefore of carbon uptake- differed in the two shrub species under study: whereas for $C$. ladanifer biomass and assimilated carbon were roughly similar in each of the components that the plant was divided in, for $E$. arborea significant differences were observed amongst the various fractions. This becomes evident in view of the values of $R$ : while the aerial part of $C$. ladanifer accounted for over $80 \%$ of the dry weight of the plant, in E. arborea it was $c a$. $65 \%$. This can be ascribed to the characteristics of the shrubs under study, such as the labdanum present in the leaves of the Cistaceae or the development of a root capable of holding the arboreal freightage of the Ericaceae. Moreover, it should also be taken into consideration that, under such environmental conditions, phenology reflects the strategy of plants to cope with the alternation of favourable and unfavourable seasons for assimilation and growth (Castro-Díez, Montserratmartí, and Cornelissen 2003).

\section{[FIG. 4]}

\section{Root-to-shoot ratios based on vibrational analysis}

The infrared spectra of the different fractions of the two shrubs under study, $C$. ladanifer and $E$. arborea, are depicted in Figure 5. The main absorption bands and their assignments are listed in Table 1.

\section{[FIG. 5] [TABLE 1]}

In the fingerprint region, four wavenumbers were selected: $1369 \mathrm{~cm}^{-1}$, attributable to in-plane bending vibrations of the $\mathrm{C}-\mathrm{H}$ and $\mathrm{C}-\mathrm{O}$ groups of the hexose ring in the cellulose; $1458 \mathrm{~cm}^{-1}$, associated with the alkane deformation of $\mathrm{CH}$ and $\mathrm{CH}_{2}$ in the saccharide backbone; $1514 \mathrm{~cm}^{-1}$, ascribed to the $\mathrm{C}=\mathrm{C}$ stretching vibration in the aromatic skeletal vibration in lignin; and $1730 \mathrm{~cm}^{-}$ ${ }^{1}$, assigned to the ester linkage of the carboxylic group of ferulic and p-coumaric acids in hemicelluloses. The corrected area values for these selected peaks are summarized in Table 2. In general terms, peak areas for E. arborea were higher than those of $C$. ladanifer, in particular those associated to thick branches and roots (which are richer in lignin for E. arborea, Table 3).

\section{[TABLE 2] [TABLE 3]}

Peak areas at $1369 \mathrm{~cm}^{-1}$ and at $1514 \mathrm{~cm}^{-1}$ were lower than those at $1730 \mathrm{~cm}^{-1}$ at $1458 \mathrm{~cm}^{-1}$. For the peak at $1369 \mathrm{~cm}^{-1}$, leaves and thin branches showed higher area values than those of roots and thick branches, due to their higher cellulose content. In Erica arborea, as regards the peak at $1514 \mathrm{~cm}^{-1}$, thick branches and roots showed peak areas higher than those of leaves and thin branches, due the higher content of lignin of the former (mature wood has high condensed lignin structures with higher molecular weight than younger tissues) (Amir et al. 2006). Conversely, for the peak at $1730 \mathrm{~cm}^{-1}$ thin branches showed the highest area values because of their higher content in hemicellulose. In relation to this latter peak, which is a hemicellulose content indicator, the areas for both the thin and thick branches proved to be the sum of the areas under the three other peaks: $6.22 \approx \sum(1.30+3.97+1.26)$; $3.90 \approx \sum(0.86+2.66+0.93) ; \quad 5.98 \approx \sum(1.20+3.04+1.03)$; $4.77 \approx \sum(1.75+2.60+0.94)$.

Regarding the $1458 \mathrm{~cm}^{-1}$ peak in leaves, the area values were the sum of the areas obtained for the other bands, both for $C$. ladanifer and $E$. arborea $\left(4.97 \approx \sum(2.71+0.84+1.30) \quad\right.$ and $6.74 \approx \sum(4.75+0.79+1.44)$, respectively). This can be explained by the fact that this band is an indicator of the overall polysaccharide content (hemicellulose, lignin and cellulose).

On the basis of previous correlations, it is possible to differentiate the roots from the other plant components, which can be grouped under the term 'shoot'. The root areas $\left(A_{\text {root }}\right)$ ranged from 0.85 to 4.56 , while shoot areas ( $\left.A_{\text {shoot }}\right)$ were in the 3.41 15.50 range for both species (Table 4).

Root-to-shoot ratios based on vibrational data $\left(R_{\mathrm{FTIR}}\right)$ for $C$. ladanifer and E. arborea, for the four selected peaks, ranged from 0.25 to 0.33 and from 0.29 to 0.53 , respectively (see Table 4). In comparison with the results based on belowground and aerial biomass $\left(R_{\text {biomass }}=0.22\right.$ for $C$. ladanifer and $R_{\text {biomass }}=0.55$ for $E$. arborea), the closest values would be those associated with the peak at $1369 \mathrm{~cm}^{-}$ 
1 (cellulose band) in the case of $C$. ladanifer $\left(R_{\mathrm{FTIR}}=0.25\right)$ and with the peak at $1514 \mathrm{~cm}^{-1}$ (lignin band) for $E$. arborea $\left(R_{\mathrm{FTIR}}=0.53\right)$. This is in agreement with the relative contents of vegetal components in the two shrubs under study: very high in cellulose for $C$. ladanifer and very high in lignin for E. arborea (Table 3).

\section{[TABLE 4]}

\section{Carbon and nitrogen concentrations}

Carbon concentrations were analysed for each the different components of the two shrubs (Table 5), omitting the one for $C$. ladanifer capsules due to its low representativeness and to allow comparison between the components of both species. The value of the carbon content (albeit slightly higher in the leaves) did not vary in a significant manner as regards the aerial and root parts, with values of $48.38 \pm 1.02 \%$ for $C$. ladanifer and $50.56 \pm 1.38 \% \mathrm{E}$. arborea. These values are in excellent agreement with those reported by Montero, Pasalodos-Tato, Montoto, et al. (2013) for the aerial part of the same species $\quad(49.70 \pm 0.66 \%$ and $51.43 \pm 1.17 \%$, respectively), to the Spanish Forest Map 1:25,000 (MFE25) values $(49.64 \pm 1.04 \%$ and $50.57 \pm 1.62 \%$, respectively) and are very close to the $50 \%$ value proposed by IPCC (2006).

\section{[TABLE 5]}

In relation to the amount of nitrogen per unit mass, it was maximum in the leaves for both species (18.89 $\mathrm{mg} \cdot \mathrm{g}^{-1}$ and $10.46 \mathrm{mg} \cdot \mathrm{g}^{-1}$ for C. ladanifer and E. arborea, respectively). The dissimilarity in the contents of $\mathrm{N}$ in the leaves between $\mathrm{Cl}$ and $\mathrm{Ea}$ (Table 5) can be explained according to equation 4 , provided that $S$ is substantially higher in $C$. ladanifer than in $E$. arborea and that $P$ is three times higher in April-May in species of genus Cistus (Cistus incanus) than in species of genus Erica (Erica multiflora) according to Catoni and Gratani (2014).

The distribution of nitrogen content, which resembles an inverse pyramid, reaching its maximum nitrogen content in the leaves and gradually decreasing as we move towards the root, where it presents its minimum, is consistent with that reported by García Rosa (2013) for fractions of C. ladanifer of different ages. Nonetheless, the value obtained in this study $(1.89 \%)$ is higher than that found by García Rosa (2013), around $0.91 \%$.

In the gum rockrose, the second highest nitrogen content -albeit substantially lower- corresponded to the thin branches $\left(8.42 \mathrm{mg} \cdot \mathrm{g}^{-1}\right)$, followed by the roots $\left(3.62 \mathrm{mg} \cdot \mathrm{g}^{-1}\right)$ and by the thick branches $(2.66$ $\left.\mathrm{mg} \cdot \mathrm{g}^{-1}\right)$. Conversely, in the briar root the leaves were followed by the thick branches $\left(3.78 \mathrm{mg} \cdot \mathrm{g}^{-1}\right)$ and by thin branches and roots (with almost identical values, 3.41 and $3.40 \mathrm{mg} \cdot \mathrm{g}^{-1}$, respectively). If the nitrogen content is analyzed considering the biomass of each fraction (Figure 6), it may be observed that the behavior is very different in the two species: the values for the analyzed fractions of $C$. ladanifer followed the order leaves $>$ thin branches $>$ thick branches $>$ roots, which was almost reversed to that in $E$. arborea: thick branches $>$ roots $>$ thin branches $>$ leaves.

\section{[FIGURE 6]}

\section{Carbon stocks}

Upon calculation of the aboveground biomass for each of the species, according to Montero, Pasalodos-Tato, López-Senespleda, et al. (2013) (equations 5 and 6), the total amount of carbon stored (Table 6) was estimated with equation 7 , using the previously determined root-to-shoot ratios (Table 4) and the carbon concentrations in each of the fractions (Table 5). The carbon dioxide equivalent was obtained by direct conversion of the carbon stock using the ratio of their atomic weights $(44 / 12)$.

\section{[TABLE 6]}

In relation to the biomass (dry matter) values, the obtained value for C. ladanifer $\left(25.45 \mathrm{t} \mathrm{DW} \cdot \mathrm{ha}^{-1}\right)$ was significantly higher than those reported by Alías Gallego et al. (2009) (13.82 t DW·ha $\left.{ }^{-1}\right)$ and García Rosa (2013) (17 t $\left.\cdot \mathrm{ha}^{-1}\right)$, but was similar to those reported by Basanta (1982) $\left(27.26 \mathrm{t} \mathrm{DW} \cdot \mathrm{ha}^{-1}\right)$ or by Terradas (2001) $\left(25 \mathrm{t} \mathrm{DW} \cdot \mathrm{ha}^{-1}\right)$.

It should be mentioned that, although the aboveground biomass value for E. arborea $(25.61 \mathrm{t}$ DW $\cdot$ ha $^{-1}$ ) was only $19 \%$ higher than that reported by Navarro (2004) $\left(21.39 \mathrm{t} \mathrm{DW} \cdot \mathrm{ha}^{-1}\right)$, the total biomass value $\left(39.70 \mathrm{t} \mathrm{DW} \cdot \mathrm{ha}^{-1}\right)$ would be $85 \%$ higher than Navarro's estimation. Therefore, regardless of whether biomass multiplied by carbon concentration or carbon equations are directly used for carbon quantification, omitting the belowground biomass would be misleading, as stated by Koehler, Watzlawick, and Kirchner (2002), and it would seriously affecting the accuracy of carbon stock estimates. 
The carbon stock values for $C$. ladanifer (10.07 $\mathrm{tC} \cdot \mathrm{ha}^{-1}$ and $2.19 \mathrm{tC} \cdot \mathrm{ha}^{-1}$ for the shoots and roots, respectively) were -as expected- higher than those reported by Alías et al. (2015), García Rosa (2013): $8.05 \mathrm{tC} \cdot \mathrm{ha}^{-1}$ and $1.41 \mathrm{tC} \cdot \mathrm{ha}^{-1}$, respectively. Nonetheless, these differences may be ascribed to the fact the latter are average values for specimens of very different ages (ranging from 0-2 year-old to 25-55 year-old specimens), whereas the specimens studied in this work were much more homogeneous (25-35 year-old specimens) and the associated biomass would be at its maximum (as noted by García Rosa (2013)).

It is also worth noting that the biomass values for both species were significantly higher than those of other shrubs: $c a .16 \mathrm{t} \cdot \mathrm{ha}^{-1}, 14 \mathrm{t} \cdot \mathrm{ha}^{-1}, 8.36 \mathrm{t} \cdot \mathrm{ha}^{-1}$, and $3.17 \mathrm{t}^{-\mathrm{ha}^{-1}}$ for Asparagus albus, Genista sp., Rosmarinus officinalis and Retama sphaerocarpa, respectively (García Rosa 2013). In turn, the carbon sequestration associated to $C$. ladanifer and E.arborea shrublands would also be significantly higher.

\section{Conclusions}

In this work, different fractions of two shrub species present in significant volumes in Mediterranean areas, namely Cistus ladanifer and Erica arborea, have been studied by several techniques. A faster, cheaper and less timeconsuming method for root-to-shoot ratio calculation based on vibrational data has been proposed: by using the areas under selected peaks in the infrared spectra, an excellent agreement with the results from UN-ECE/FAO-IPCC/Sanquetta et al. methodology ( $\left.R_{\text {biomass }}\right)$ was obtained, attaining the best correspondences for the peak at $1369 \mathrm{~cm}^{-1}$ (cellulose band) in the case of $C$. ladanifer $\left(R_{\mathrm{FTIR}}=0.25 ; R_{\mathrm{biomass}}=0.22\right)$ and for the peak at 1514 $\mathrm{cm}^{-1}$ (lignin band) for E. arborea $\left(R_{\mathrm{FTIR}}=0.53\right.$; $\left.R_{\text {biomass }}=0.55\right)$. The elemental analysis confirmed that the percentage of carbon in the aerial and radical fractions did not differ in a significant manner, so the use of a 0.5 global value for the entire plant can be deemed as appropriate for both species. The percentage distribution of the biomass showed significant differences between the two species. As regards carbon storage, since carbon content did not depend on the analyzed fraction but was directly related to biomass, it could then be directly quantified from the aerial biomass (which is relatively easy to determine) using the root-toshoot ratios. The carbon stock values (12.27 and $19.86 \mathrm{tC} \cdot \mathrm{ha}^{-1}$ for C. ladanifer and E. arborea, respectively) were substantially higher than those of other shrubs, evincing the importance of these two shrubs species for the mitigation of Climate Change and their suitability for ecological restoration purposes, in particular for poor soils.

\section{Conflict of interest}

The authors declare no competing financial interests.

\section{References}

Agren, G. I., and T. Ingestad. 1987. "Root: shoot ratio as a balance between nitrogen productivity and photosynthesis." Plant, Cell and Environment 10 (7):579-586. doi: 10.1111/1365-3040.ep11604105.

Alías Gallego, J. C., M. García Rosa, C. Valares Masa, T. Sosa Díaz, and N. Chaves Lobón. 2009. "El matorral como sumidero de carbono." V Congreso Forestal Español, Ávila, Spain.

Alías, J. C., M. García, T. Sosa, C. Valares, and N. Chaves. 2015. "Carbon storage in the different compartments of two systems of shrubs of the southwestern Iberian Peninsula." Agroforestry Systems 89 (4):575-585. doi: 10.1007/s10457-0159792-z.

Amir, S., M. Hafidi, L. Lemee, G. Merlina, M. Guiresse, E. Pinelli, J. C. Revel, J. R. Bailly, and A. Ambles. 2006. "Structural characterization of humic acids, extracted from sewage sludge during composting, by thermochemolysis-gas chromatographymass spectrometry." Process Biochemistry $41 \quad$ (2):410-422. doi: 10.1016/j.procbio.2005.07.005.

Baker, Matthew J., Júlio Trevisan, Paul Bassan, Rohit Bhargava, Holly J. Butler, Konrad M. Dorling, Peter R. Fielden, Simon W. Fogarty, Nigel J. Fullwood, Kelly a Heys, Caryn Hughes, Peter Lasch, Pierre L. Martin-Hirsch, Blessing Obinaju, Ganesh D. Sockalingum, Josep Sulé-Suso, Rebecca J. Strong, Michael J. Walsh, Bayden R. Wood, Peter Gardner, and Francis L. Martin. 2014. "Using Fourier transform IR spectroscopy to analyze biological materials." Nature protocols 9 (8):177191. doi: 10.1038/nprot.2014.110.

Barboni, Toussaint, Grazia Pellizzaro, Bachisio Arca, Nathalie Chiaramonti, and Pierpaolo Duce. 2010. "Analysis and origins of volatile organic compounds smoke from ligno-cellulosic fuels." Journal of 
Analytical and Applied Pyrolysis 89 (1):6065. doi: 10.1016/j.jaap.2010.05.006.

Basanta, A. 1982. "Vegetación serial en Sierra Morena. Estudio ecológico de las respuestas del matorral a distintas intervenciones en el Coto Nacional "La Pata del Caballo" (Huelva)." PhD, Universidad de Sevilla.

Blanco Oyonarte, P., and R. M. Navarro Cerrillo. 2003. "Aboveground phytomass models for major species in shrub ecosystems of western Andalusia." Forest Systems 12 (3):47-55. doi: 10.5424/1078.

Castro-Díez, Pilar, Gabriel Montserrat-martí, and J. H. C. Cornelissen. 2003. "Trade-offs between phenology, relative growth rate, life form and seed mass among 22 Mediterranean woody species." Plant Ecology $166 \quad$ (1):117-129. doi: 10.1023/a:1023209230303.

Castro, Isabel, Miguel Ángel Casado, Lucía Ramírez-Sanz, José Manuel de Miguel, Margarita Costa, and Francisco Díaz Pineda. 1996. "Funciones de estimación de la biomasa aérea de varias especies del matorral mediterráneo del centro de la península Ibérica." Orsis : Organismes $i$ Sistemes 11:107-116.

Catoni, Rosangela, and Loretta Gratani. 2014. "Variations in leaf respiration and photosynthesis ratio in response to air temperature and water availability among Mediterranean evergreen species." Journal of Arid Environments 102:82-88. doi: 10.1016/j.jaridenv.2013.11.013.

Cerrillo, R. M. Navarro, and P. Blanco Oyonarte. 2006. "Estimation of above-ground biomass in shrubland ecosystems of southern Spain." Investigación agraria. Sistemas y recursos forestales 15 (2):197207. doi: $10.5424 / \mathrm{srf} / 2006152-00964$.

Chen, Huilun, Carlo Ferrari, Marco Angiuli, Jun Yao, Costantino Raspi, and Emilia Bramanti. 2010. "Qualitative and quantitative analysis of wood samples by Fourier transform infrared spectroscopy and multivariate analysis." Carbohydrate Polymers $82 \quad$ (3):772-778. doi: 10.1016/j.carbpol.2010.05.052.

de Mello, Anabel, Leif Nutto, Karla Weber, Carlos Sanquetta, Jorge Monteiro de Matos, and Gero Becker. 2012. "Individual biomass and carbon equations for Mimosa scabrella Benth. (bracatinga) in southern Brazil."
Silva Fennica 46 (3):333-343. doi: 10.14214/sf.44.

Emmanuel, Vartanian, Barres Odile, and Roque Céline. 2015. "FTIR spectroscopy of woods: A new approach to study the weathering of the carving face of a sculpture." Spectrochimica Acta - Part A: Molecular and Biomolecular Spectroscopy 136 (Part C):1255-1259. doi: 10.1016/j.saa.2014.10.011.

Evans, P. A. 1991. "Differentiating "hard" from "soft" woods using Fourier transform infrared and Fourier transform spectroscopy." Spectrochimica Acta Part A: Molecular Spectroscopy 47 (910):1441-1447. doi: 10.1016/05848539(91)80235-b.

Faust, Ben. 1997. Modern Chemical Techniques : An Essential Reference for Students and Teachers: Royal Society of Chemistry.

Federici, Sandro, Francesco N. Tubiello, Mirella Salvatore, Heather Jacobs, and Josef Schmidhuber. 2015. "New estimates of CO2 forest emissions and removals: 19902015." Forest Ecology and Management 352:89-98. doi: 10.1016/j.foreco.2015.04.022.

Ferro, Miguel D., Maria C. Fernandes, Ana F. C. Paulino, Sónia O. Prozil, Janis Gravitis, Dmitry V. Evtuguin, and Ana M. R. B. Xavier. 2015. "Bioethanol production from steam explosion pretreated and alkali extracted Cistus ladanifer (rockrose)." Biochemical Engineering Journal 104:98105. doi: 10.1016/j.bej.2015.04.009.

García Rosa, María. 2013. "Estudio de la biomasa de Cistus ladanifer L. y Retama sphaerocarpa L. como sumidero de $\mathrm{CO}_{2}$ : existencias y potencialidad." Departamento de Biología Vegetal, Ecología y Ciencias de la Tierra, Universidad de Extremadura, Universidad de Extremadura. España (http://hdl.handle.net/10662/577).

Gayoso A, Jorge, and Javier Guerra C. 2005. "Contenido de carbono en la biomasa aérea de bosques nativos en Chile." Bosque (Valdivia) $26 \quad$ (2):33-38. doi: 10.4067/s0717-92002005000200005.

Griffiths, Peter R., and James A. De Haseth. 2007. Fourier Transform Infrared Spectrometry: John Wiley \& Sons.

Hilbert, D. W. 1990. "Optimization of Plant Root: Shoot Ratios and Internal Nitrogen Concentration." Annals of Botany 66 (1):91-99. 
Huck, Christian W. 2015. "Advances of infrared spectroscopy in natural product research." Phytochemistry Letters 11:384-393. doi: 10.1016/j.phytol.2014.10.026.

Ibàñez, J. J., J. Vayreda, and C. Gracia. 2002. "Metodología complementaria al Inventario Forestal Nacional en Catalunya." In El Inventario Forestal Nacional. Elemento clave para la Gestión Forestal Sostenible, edited by F. Bravo, M. Del Río and C. Del Peso, 67-77. Fundación General de la Universidad de Valladolid.

IPCC. 2006. 2006 IPCC Guidelines for National Greenhouse Gas Inventories - Agriculture, Forestry and Other Land Use. Edited by H.S. Eggelston, L. Buendia, K. Miwa, T. Ngara and K. Tanabe. Vol. 4, Guidelines for National Greenhouse Gas Inventories. Hayama, Japan: IPCC National Greenhouse Gas Inventories Programme Institute for Global Environmental Strategies.

Kauppi, P. E., K. Mielikainen, and K. Kuusela. 1992. "Biomass and Carbon Budget of European Forests, 1971 to 1990." Science 256 (5053):70-74. doi: 10.1126/science. 256.5053.70.

Kauppi, Pekka E., Erkki Tomppo, and Ari Ferm. 1995. "C and $\mathrm{N}$ storage in living trees within Finland since 1950s." Plant and Soil 168-169 (1):633-638. doi: 10.1007/bf00029377.

Koehler, E. S., L. F. Watzlawick, and F. F. Kirchner. 2002. "Fontes e níveis de erros nas estimativas do potencial de fixação de carbono." In As florestas e o carbono, edited by C. R. Sanquetta, L. F. Watzlawick, R. Balbinot, M. A. B. Ziliotto and F. S. Gomes, 251-264. Curitiba, Brasil: Imprensa Universitaria da UFPR.

Kollmann, Franz. 1959. Tecnología de la madera y sus aplicaciones. 2 vols. Madrid, Spain: Instituto Forestal de Investigaciones y Experiencias y Servicios de la Madera. Ministerio de Agricultura.

Leroy, Valrie, Eric Leoni, and Dominique Cancellieri. 2010. "Thermal Degradation of Lignocellulosic Fuels: Biopolymers Contribution." In Biopolymers, edited by Magdy Elnashar, 303-318. Rijeka, Croatia: InTech.

Lin, Y. J., C. P. Liu, and J. C. Lin. 2002. "Measurement of specific gravity and carbon content of important timber species in Taiwan." Taiwan Journal of Forest Science 17 (3):291-299.

Löwe, Helmut, Günther Seufert, and Frank Raes. 2000. "Comparison of methods used within Member States for estimating $\mathrm{CO}_{2}$ emissions and sinks according to UNFCCC and EU Monitoring Mechanism: forest and other wooded land." Biotechnologie, agronomie, société et environnement 4 (4):315-319.

Lloret, F., C. Casanovas, and J. Penuelas. 1999. "Seedling survival of Mediterranean shrubland species in relation to root:shoot ratio, seed size and water and nitrogen use." Functional Ecology 13 (2):210-216. doi: 10.1046/j.1365-2435.1999.00309.x.

MAPAMA. 2006. "Spanish Forest Map (MFE50)." Spanish Ministry of Agriculture, Food and Environment.

http://www.mapama.gob.es/es/biodiversid ad/servicios/banco-datosnaturaleza/informaciondisponible/mfe50.aspx.

MAPAMA. 2016. "Spanish National Forest Inventory." Spanish Ministry of Agriculture, Food and Environment. http://www.mapama.gob.es/es/desarrollorural/temas/politica-forestal/inventariocartografia/inventario-forestal-nacional/.

Masalles, R. M., and J. Vigo. 1987. "La successió a les terres mediterrànies: sèries de vegetació." In Ecosistemes terrestres: la resposta als incendis $i$ a d'altres pertorbacions, edited by J. Terradas, 27-43. Barcelona, Spain: Quaderns d'Ecologia Aplicada.

Mendoza-Ponce, Alma, and Leopoldo Galicia. 2010. "Aboveground and belowground biomass and carbon pools in highland temperate forest landscape in Central Mexico." Forestry 83 (5):497-506. doi: 10.1093/forestry/cpq032.

Mokany, Karel, R. John Raison, and Anatoly S. Prokushkin. 2006. "Critical analysis of root:shoot ratios in terrestrial biomes." Global Change Biology 12 (1):84-96. doi: 10.1111/j.1365-2486.2005.001043.x.

Montero, G, M Pasalodos-Tato, E LópezSenespleda, R Onrubia, and G Madrigal. 2013. "Ecuaciones para la estimación de la biomasa en matorrales y arbustedos mediterráneos." $6^{\circ}$ Congreso Forestal Español, Vitoria-Gasteiz, Spain, June 1014, 2013. 
Montero, G., M Pasalodos-Tato, R. Montoto, E. Lopez-Senespleda, R. Onrubia, A. BravoOviedo, and R Ruiz-Peinado. 2013. "Contenido de Carbono en la biomasa de las principales especies de matorral y arbustedos de España." $6^{\circ}$ Congreso Forestal Español, Vitoria-Gasteiz, Spain, June 10-14, 2013.

Montero, Gregorio, Ricardo Ruiz-Peinado, and Marta Muñoz. 2005. Producción de biomasa y fijación de $\mathrm{CO}_{2}$ por los bosques españoles. Vol. 13, Monografías INIA: Serie Forestal. Madrid, Spain: Instituto Nacional de Investigación y Tecnología Agraria y Alimentaría (INIA).

Navarro, Rafael M. 2004. "Fitomasa aérea en los ecosistemas de matorral en el monte Can Vilallonga (T.M. DE Cassà de la SelvaGirona)." Ecología 18:99-112.

Orellana-Rivadeneyra, G., M.L. Sandoval-Saolís, G. Linares-Fleites, N.E. García Calderón, and J.V.; Tamariz-Flores. 2012. "Description of the carbon dynamics in forest soils using a model of reservoirs." Avances en Ciencias e Ingeniería 3 (1):123-135.

Owen, N. L., and D. W. Thomas. 1989. "Infrared studies of "hard" and "soft" woods." Applied Spectroscopy 43 (3):451-455. doi: 10.1366/0003702894202760.

Paton, D., R. Osorio, P. Azocar, H. Bote, A. Matas, and J. Tovar. 1997. "Prediction of browsing biomass of certain shrub species from arid Mediterranean climate of North Chile by multicriteria analysis." Archivos de zootecnia 46 (175):225-237.

Ruiz-Peinado, R., G. Montero, and M. Del Rio. 2012. "Biomass models to estimate carbon stocks for hardwood tree species." Forest Systems $21 \quad$ (1):42-52. doi: 10.5424/fs/2112211-02193.

Ruiz-Peinado, Ricardo, Miren del Rio, and Gregorio Montero. 2011. "New models for estimating the carbon sink capacity of Spanish softwood species." Forest Systems 20 (1):176-188.

Sanquetta, C.R., A.P.D. Corte, R. Balbinot, and M.A.B. Zilliotto. 2004. "Proposta metodológica para quantificação e monitoramento do carbono estocado em florestas plantadas." In Mercado de carbono: mercado e ciência, edited by C.R. Sanquetta and M.A.B. Zilliotto, 240-255. Curitiba, Brazil: UFPR / ECOPLAN.
Sanquetta, Carlos R., Ana P. D. Corte, and Fernando da Silva. 2011. "Biomass expansion factor and root-to-shoot ratio for Pinus in Brazil." Carbon Balance and Management 6 (6):1-8. doi: 10.1186/17500680-6-6.

Schenk, H. Jochen, and Robert B. Jackson. 2002. "Rooting depths, lateral root spreads and below-ground/above-ground allometries of plants in water-limited ecosystems." Journal of Ecology 90 (3):480-494. doi: 10.1046/j.1365-2745.2002.00682.x.

Schwanninger, M., J. C. Rodrigues, H. Pereira, and B. Hinterstoisser. 2004. "Effects of shorttime vibratory ball milling on the shape of FT-IR spectra of wood and cellulose." Vibrational Spectroscopy 36 (1):23-40. doi: 10.1016/j.vibspec.2004.02.003.

Serrada, R., G. Montero, and J.A. Reque Kilchenmann. 2008. Compendium of applied forestry in Spain. Madrid, Spain: Instituto Nacional de Investigación y Tecnología Agraria y Alimentaria (INIA).

Somogyi, Z, E Cienciala, $\mathrm{R}$ Mäkipää, $\mathrm{P}$ Muukkonen, A Lehtonen, and $\mathrm{P}$ Weiss. 2007. "Indirect methods of large-scale forest biomass estimation." European Journal of Forest Research 126 (2):197207. doi: 10.1007/s10342-006-0125-7.

Spanish Biodiversity Foundation, and Spanish Royal Botanic Garden. 2011. "Anthos. Spanish plants information system." Spanish Ministry of Agriculture, Food and Environment and Spanish State Agency for National Research Council. http://www.anthos.es/index.php?lang=en.

Terradas, J. 2001. Ecología de la vegetación: de la ecofisiología de las plantas a la dinámica de comunidades y paisajes. Barcelona, Spain: Omega.

Traoré, Mohamed, Joeri Kaal, and Antonio Martínez Cortizas. 2016. "Application of FTIR spectroscopy to the characterization of archeological wood." Spectrochimica Acta - Part A: Molecular and Biomolecular Spectroscopy 153:63-70. doi: 10.1016/j.saa.2015.07.108.

UN-ECE/FAO. 2000. Forest resources of Europe, CIS, North America, Australia, Japan, and New Zealand (industrialized temperate/boreal countries) : UNECE/FAO contribution to the Global Forest Resources Assessment 2000. Vol. 17, Geneva timber and forest study papers. New York, USA: United Nations, 
Economic Commission for Europe, Timber Section; Food and Agriculture Organization of the United Nations.

Wang, Jinchuang, Baoli Duan, and Yuanbin Zhang. 2011. "Effects of experimental warming on growth, biomass allocation, and needle chemistry of Abies faxoniana in even-aged monospecific stands." Plant Ecology 213 (1):47-55. doi: 10.1007/s11258-011-00051.

Watson, Robert T., and Ian R. Noble. 2002. "Carbon and the Science-Policy Nexus: The Kyoto Challenge." In Challenges of a Changing Earth, edited by Will Steffen, Jill Jäger, David J. Carson and Clare Bradshaw, 57-64. Berlin, Heidelberg: Springer Berlin Heidelberg. 


\section{Tables}

Table 1. Main absorption bands in the FTIR spectra of the different fractions of $C$. ladanifer and $E$. arborea and their assignments according to the literature (Emmanuel, Odile, and Céline 2015, Faust 1997, Schwanninger et al. 2004, Traoré, Kaal, and Martínez Cortizas 2016).

\begin{tabular}{|c|c|c|c|c|c|c|c|c|c|c|}
\hline \multicolumn{8}{|c|}{ Wavenumber $\left(\mathrm{cm}^{-1}\right)$} & \multirow{2}{*}{ Vegetal component } & \multirow{2}{*}{ Bonds } & \multirow{2}{*}{ Assignment } \\
\hline $\mathrm{LCl}$ & $\mathrm{tCl}$ & $\mathrm{T} \mathrm{Cl}$ & $\mathrm{R} \mathrm{Cl}$ & $\mathrm{L} E a$ & $\mathrm{t} E a$ & $\mathrm{TE} E a$ & $\mathrm{R} E a$ & & & \\
\hline \multirow[t]{2}{*}{1035} & 1050 & 1035 & 1035 & 1035 & 1050 & 1039 & 1031 & Cellulose, hemicellulose, lignin & $\begin{array}{l}\mathrm{C}-\mathrm{O}, \mathrm{C}=\mathrm{C} \\
\text { and } \mathrm{C}-\mathrm{C}-\mathrm{O}\end{array}$ & $\begin{array}{l}\text { Aromatic } \mathrm{C}-\mathrm{H} \text { in plane deformation; plus } \mathrm{C}-\mathrm{O} \text { deformation in primary } \\
\text { alcohols; plus } \mathrm{C}=\mathrm{O} \text { stretch (unconjugated) }\end{array}$ \\
\hline & & & & & & & 1081 & Cellulose & $\mathrm{C}-\mathrm{H}$ & $\mathrm{C}-\mathrm{O}$ deformation in secondary alcohols and aliphatic ethers \\
\hline 1164 & & & & & & & 1155 & Cellulose & $\mathrm{C}-\mathrm{H}$ & $\mathrm{C}-\mathrm{O}-\mathrm{C}$ asymmetric valence vibration, $\mathrm{C}=\mathrm{O}$ stretching in aliphatic groups \\
\hline 1233 & 1243 & 1243 & 1251 & 1243 & 1247 & 1247 & 1247 & Lignin & $\mathrm{C}-\mathrm{H}$ & $\mathrm{C}-\mathrm{C}$ plus $\mathrm{C}-\mathrm{O}$ plus $\mathrm{C}=\mathrm{O}$ stretching $(\mathrm{OH}$ plane deformation, also $\mathrm{COOH})$ \\
\hline 1317 & 1320 & 1320 & 1321 & & 1331 & 1332 & & Cellulose, hemicellulose, lignin & $\mathrm{C}-\mathrm{O}, \mathrm{CH}_{2}$ & $\begin{array}{l}\text { Condensation of guaiacyl unit and syringyl unit, syringyl unit and } \mathrm{CH}_{2} \\
\text { bending stretching; } \mathrm{CH}_{2} \text { rocking vibration }\end{array}$ \\
\hline 1367 & 1375 & 1375 & 1375 & 1373 & 1375 & 1375 & 1374 & Cellulose & $\mathrm{C}-\mathrm{H}$ & In-plane bending vibration of the $\mathrm{C}-\mathrm{H}$ and $\mathrm{C}-\mathrm{O}$ groups of the hexose ring \\
\hline 1455 & 1458 & 1457 & 1456 & 1455 & 1464 & 1459 & 1452 & Saccharide backbone & $\mathrm{C}-\mathrm{H}$ & $\begin{array}{l}\text { Alkane deformation relating to } \mathrm{CH} \text { and } \mathrm{CH}_{2} \text {, consistent with the saccharide } \\
\text { backbone }\end{array}$ \\
\hline 1515 & 1508 & 1508 & 1509 & 1517 & 1508 & 1513 & 1513 & Lignin & $\mathrm{C}=\mathrm{C}$ & Stretching vibration in the aromatic skeletal vibration \\
\hline 1615 & 1618 & 1617 & 1617 & 1616 & 1617 & 1617 & 1618 & Cellulose, lignin & $\mathrm{O}-\mathrm{H}, \mathrm{C}-\mathrm{O}$ & Absorbed $\mathrm{O}-\mathrm{H}$ and conjugated $\mathrm{C}-\mathrm{O}$ lignin or cellulose \\
\hline 1733 & 1735 & 1735 & 1736 & 1733 & 1739 & 1740 & 1736 & Hemicellulose + lignin & $\mathrm{C}=\mathrm{O}$ & Ester linkage of the carboxylic group of ferulic and p-coumaric acids \\
\hline 2850 & & & & 2852 & & & & Cellulose, hemicellulose, lignin & $\mathrm{CH}$ stretch & Symmetric $\mathrm{CH}_{2}$ valence vibration \\
\hline 2919 & 2921 & 2920 & 2919 & 2923 & 2918 & 2919 & 2928 & Cellulose, hemicellulose, lignin & $\mathrm{CH}$ stretch & \\
\hline 3389 & 3413 & 3421 & 3405 & 3374 & 3409 & 3409 & 3405 & Lignin & $\mathrm{O}-\mathrm{H}$ & Intramolecular $\mathrm{O}_{3}-\mathrm{H}^{\cdots} \mathrm{O}_{5}{ }^{\prime}$ in cellulose \\
\hline
\end{tabular}

Cl: Cistus ladanifer; Ea: Erica arborea; L: leaves; t: thin branches; T: thick branches; R: roots. 
Table 2. Corrected areas values for each fraction in C. ladanifer and E. arborea.

\begin{tabular}{ccccccccr}
\hline \multirow{2}{*}{$\begin{array}{c}\text { Wavenumber } \\
\left(\mathrm{cm}^{-1}\right)\end{array}$} & \multicolumn{4}{c}{ Cistus ladanifer L. } & \multicolumn{4}{c}{ Erica arborea L. } \\
\cline { 2 - 8 } & Leaves & $\begin{array}{c}\text { Thin } \\
\text { branches }\end{array}$ & $\begin{array}{c}\text { Thick } \\
\text { branches }\end{array}$ & Roots & Leaves & $\begin{array}{c}\text { Thin } \\
\text { branches }\end{array}$ & $\begin{array}{c}\text { Thick } \\
\text { branches }\end{array}$ & Roots \\
\hline 1730 & 2.71 & 6.22 & 3.90 & 4.21 & 4.75 & 5.98 & 4.77 & 4.56 \\
1514 & 0.84 & 1.30 & 0.86 & 0.85 & 0.79 & 1.20 & 1.75 & 1.97 \\
1458 & 4.97 & 3.97 & 2.66 & 2.87 & 6.74 & 3.04 & 2.60 & 3.55 \\
1369 & 1.30 & 1.26 & 0.93 & 0.88 & 1.44 & 1.03 & 0.94 & 1.15 \\
\hline
\end{tabular}

Table 3. Percentages in terms of vegetal components for C. ladanifer and E. arborea (Ferro et al. 2015, Barboni et al. 2010, Leroy, Leoni, and Cancellieri 2010).

\begin{tabular}{ccc}
\hline & Cistus ladanifer & Erica arborea \\
\hline Cellulose (\%) & $54.9-55.7$ & $37.3-41.1$ \\
Lignin (\%) & $24.5-34.2$ & $39.3-40.1$ \\
Hemi-cellulose (\%) & $10.1-10.9$ & $9.7-13.8$ \\
Extractive (\%) & $9.4-9.6$ & $5.7-11.0$ \\
\hline
\end{tabular}

Table 4. Comparison of root-to-shoot ratios for $C$. ladanifer and $E$. arborea determined by two methodologies: using vibrational data $\left(R_{\mathrm{FTIR}}\right)$ and using the UN-ECE/FAO-IPCC procedure modified by Sanquetta, Corte, and da Silva (2011) ( $\left.R_{\text {biomass }}\right)$.

\begin{tabular}{|c|c|c|c|c|c|c|c|c|}
\hline & \multicolumn{4}{|c|}{ C. Iadanifer } & \multicolumn{4}{|c|}{ E. arborea } \\
\hline \multicolumn{9}{|l|}{ FTIR method } \\
\hline Wavenumber $\left(\mathrm{cm}^{-1}\right)$ & 1730 & 1514 & 1458 & 1369 & 1730 & 1514 & 1458 & 1369 \\
\hline Root area & 4.21 & 0.85 & 2.87 & 0.88 & 4.56 & 1.97 & 3.55 & 1.15 \\
\hline Shoot area & 12.83 & 3.00 & 11.60 & 3.49 & 15.50 & 3.74 & $12-38$ & $3-41$ \\
\hline$R_{\mathrm{FTIR}}$ & 0.33 & 0.28 & 0.25 & $\underline{0.25}$ & 0.29 & $\underline{0.53}$ & 0.29 & 0.34 \\
\hline \multicolumn{9}{|c|}{ UN-ECE/FAO-IPCC modified by Sanquetta } \\
\hline$R_{\text {biomass }}$ & \multicolumn{4}{|c|}{0.22} & \multicolumn{4}{|c|}{0.55} \\
\hline
\end{tabular}

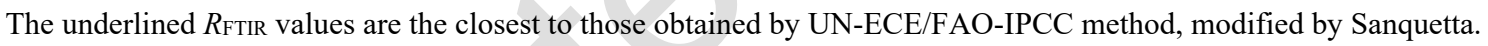

Table 5. C content, $\mathrm{N}$ content and $\mathrm{C}: \mathrm{N}$ ratios for C. ladanifer and E. arborea.

\begin{tabular}{|c|c|c|c|c|c|c|c|c|}
\hline & \multicolumn{4}{|c|}{ Cistus Iadanifer $L$. } & \multicolumn{4}{|c|}{ Erica arborea $L}$. \\
\hline & Leaves & Thin branches & Thick branches & Roots & Leaves & Thin branches & Thick branches & Roots \\
\hline $\mathrm{C}$ content $\left(\mathrm{mg} \cdot \mathrm{g}^{-1}\right)$ & $\begin{array}{l}500.72 \\
(0.37)\end{array}$ & $\begin{array}{c}481.20 \\
(0.27)\end{array}$ & $\begin{array}{c}475.60 \\
(0.59)\end{array}$ & $\begin{array}{l}477.76 \\
(0.47)\end{array}$ & $\begin{array}{l}528.20 \\
(0.22)\end{array}$ & $\begin{array}{c}493.38 \\
(0.13)\end{array}$ & $\begin{array}{c}502.62 \\
(0.31)\end{array}$ & $\begin{array}{l}498.24 \\
(1.23)\end{array}$ \\
\hline $\mathrm{N}$ content $\left(\mathrm{mg} \cdot \mathrm{g}^{-1}\right)$ & $\begin{array}{l}18.89 \\
(0.02)\end{array}$ & $\begin{array}{c}8.42 \\
(0.00)\end{array}$ & $\begin{array}{c}2.66 \\
(0.18)\end{array}$ & $\begin{array}{c}3.62 \\
(0.02)\end{array}$ & $\begin{array}{l}10.46 \\
(0.03)\end{array}$ & $\begin{array}{c}3.41 \\
(0.18)\end{array}$ & $\begin{array}{c}3.78 \\
(0.04)\end{array}$ & $\begin{array}{c}3.40 \\
(0.16)\end{array}$ \\
\hline C:N ratio & $\begin{array}{l}26.50 \\
(0.05)\end{array}$ & & & & $\begin{array}{l}50.52 \\
(0.14) \\
\end{array}$ & & & \\
\hline
\end{tabular}

All values are given in average \pm standard deviations (in brackets).

Table 6. Estimated biomass (dry matter), carbon stock and carbon dioxide equivalent.

\begin{tabular}{cccccccccc}
\hline & \multicolumn{3}{c}{ Biomass $\left(\mathrm{t} \mathrm{DW} \cdot \mathrm{ha}^{-1}\right)$} & \multicolumn{3}{c}{ Carbon stock $\left(\mathrm{tC} \cdot \mathrm{ha}^{-1}\right)$} & \multicolumn{3}{c}{$\mathrm{CO}_{2}$ eq $\left(\mathrm{t} \mathrm{CO}_{2} \mathrm{eq}^{\cdot} \mathrm{ha}^{-1}\right)$} \\
\cline { 2 - 10 } & Shoot & Root & Total & Shoot & Root & Total & Shoot & Root & Total \\
\hline C. ladafiner & 20.86 & 4.59 & 25.45 & 10.07 & 2.19 & 12.27 & 36.94 & 8.04 & 44.97 \\
E. arborea & 25.61 & 14.09 & 39.70 & 12.84 & 7.02 & 19.86 & 47.07 & 25.73 & 72.80 \\
\hline
\end{tabular}




\section{Figure captions}

Figure 1. Cistus ladanifer L., also known as gum rockrose or labdanum (left); Erica arborea L., also known as briar root or tree heath (right).

Figure 2. Location of Castilla y León region in the Iberian Peninsula (left); location of Zamora province in Castilla y León region (center); location of the shrubland under study in Zamora province (right).

Figure 3. FTIR spectrum of E. arborea leaves with the corrected peak areas calculated at some selected wavenumbers $\left(\mathrm{cm}^{-1}\right)$.

Figure 4. Biomass distribution for Cistus ladanifer L. and Erica arborea L.

Figure 5. FTIR spectra of the different fractions (leaves, thin branches, thick branches and roots) of $(a) C$. ladanifer and (b) E. arborea.

Figure 6. Contribution of the different components to the total carbon and nitrogen stocks, for C. ladanifer and $E$. arborea, taking into consideration the biomass distribution. 